\title{
KAJIAN SENI ISLAM PADA MASJID Hj. SUDALMIYAH RAIS UNIVERSITAS MUHAMMADIYAH SURAKARTA
}

\author{
Siti Umairoh \\ Program Studi Arsitektur \\ Fakultas Teknik UMS \\ e-mail: sitiumairoh359@gmail.com
}

Widyastuti Nurjayanti

Program Studi Arsitektur

Fakultas Teknik UMS

e-mail: widyastuti.nurjayanti@ums.ac.id

\begin{abstract}
ABSTRAK
The mosque which is a place of worship or place of worship for Muslims is also the culmination of the sanctity of space in Islam and is an artifact of Islamic architecture. Islamic art forms on mosques are a blend of symbolic elements of Islamic architecture. Masjid Hj. Sudalmiyah Rais is a part of public facilities in Universitas Muhammadiyah Surakarta. The mosque has a very thick Islamic architectural style. This research will explore and find out what forms of Islamic art are applied to the mosque. The purpose of this study finds Islamic art was applied in the mosque and how to presents Islamic decorative arts found in the mosque. This study uses a qualitative descriptive method. This research carried out by seeing the object of the mosque, then assessed the parts that were based on the results of matching parameters of the symbolic elements of Islamic architecture. Masjid $\mathrm{Hj}$. Sudalmiyah Rais fulfills 11 of these 12 parameters. The missing thing is the hand made decorations. That can be concluded that Masjid Hj. Sudalmiyah Rais applied Islamic art to the physical form of the building. Islamic ornamental arts contained in the mosque that are in the form of calligraphy ornaments, geometric ornaments, and flower ornaments (florist). The benefits of this research are to increase public knowledge about Islamic art studies found in Masjid Hj. Sudalmiyah Rais and gave references to Architects about the use of Islamic art in mosques.
\end{abstract}

KEYWORDS: Islamic architecture; Islamic decoration; mosque

\section{PENDAHULUAN}

Arsitektur Islam merupakan perpaduan antara kebudayaan manusia dan proses penghambaan diri seorang manusia kepada Tuhannya, yang berada dalam keselarasan hubungan antara manusia, lingkungan dan penciptanya. Arsitektur Islam mengungkapkan hubungan geometris yang kompleks, hirarki bentuk dan ornamen, serta makna simbolis yang sangat dalam. Faktor yang mempengaruhi corak atau ragam arsitektur budaya Islam adalah kebudayaan, teknologi, dan iklim setempat. Islam sebagai agama Rahmatan lil alamin (agama rahmat bagi seluruh alam), menempatkan nilai-nilai Islami dalam setiap sendi kehidupan, tidak merusak, penuh rahmat, dan cinta kehidupan. Nilai-nilai filosofis yang ada dalam Al Qur'an dan Hadist mensyaratkan perdamaian dan kehidupan yang berkelanjutan (sustainable). Nilai-nilai Islami adalah nilai dasar islam/kaidah/pedoman/filosofi yang penting untuk dijadikan landasan bagi perkembangan peradaban Islam termasuk arsitektur, sebagai pedoman perancangan (Nurjayanti, 2011). Perwujudan arsitektur Islami merupakan ikhtiar muslim untuk menjamin keberadaan nilai-nilai Islami dalam wujud elemen fisik agar selalu sesuai dengan pedoman Islam (Nurjayanti, Ronald, 2011).
Masjid adalah salah satu bentuk arsitektur yang merupakan ungkapan fisik bangunan dari budaya masyarakat pada tempat dan jaman tertentu, dalam rangka memenuhi tuntutan kegiatan peribadatan. Arsitektur masjid di Indonesia dipengaruhi oleh berbagai tradisi dan budaya. Arsitektur masjid di Indonesia saat ini berkembang pesat. Sehingga muncul karakteristik bentuk tampilan masjid yang berbeda antara masjid baru dengan masjid-masjid lama. Perkembangan masjid hingga saat ini menunjukkan fenomena bentuk tampilan masjid masa kini atau modern. Masjid modern adalah masjid yang dibangun berdasarkan kriteria modern yaitu berdasarkan pembaruan dan kecocokan pola pikir masyarakat antara subjek dengan objeknya yang berkaitan erat dengan ruang dan waktu dan di dalamnya terdapat paham-paham moderenisme (Latif, 2015). Tampilan modern atau masjid masa kini yang mengikuti perkembangan jaman membentuk pola arsitektural baru, sehingga wujud elemen fisik masjid di era globalisasi ini memiliki estetika wajah yang beragam.

Masjid $\mathrm{Hj}$. Sudalmiyah Rais merupakan masjid yang berada di kampus 2 Universitas Muhammadiyah Surakarta, diresmikan pada bulan Desember 2017. Masjid $\mathrm{Hj}$. Sudalmiyah Rais pun tidak luput dari perkembangan jaman dan teknologi serta budaya dan 
iklim setempat yang tercermin dari gaya arsitekturnya. Untuk mengetahui bagaimanakah seni Islam yang diterapkan di masjid tersebut, maka perlu adanya kajian mengenai ciri-ciri seni Islam pada bangunan masjid Hj. Sudalmiyah Rais.

Penelitian ini bertujuan untuk menemukan Seni Islam yang diterapkan pada bangunan masjid $\mathrm{Hj}$. Sudalmiyah Rais. Adapun manfaat dari penelitian ini antara lain menambah pengetahuan masyarakat mengenai kajian seni Islam dan dapat memberi referensi bagi Arsitek tentang penggunaan seni Islam pada masjid.

Studi pustaka penelitian ini mengungkapkan studi tentang (1) Arsitektur, Arsitektur Islam dan Nilai-nilai Islami dalam Arsitektur, Ekspresi Arsitektur Islami, (2) Seni Hias Islami. Arsitektur merupakan bagian yang tidak terpisahkan dari lingkungan alam secara keseluruhan. Kondisi alam mempengaruhi proses terbentuknya kebudayaan manusia. Arsitektur yang merupakan bagian dari budaya selalu berkembang seiring dengan berkembangnya peradaban manusia. Oleh karena itu, Islam sebagai bagian dari berkembangnya peradaban manusia juga memiliki budaya berarsitektur. Budaya arsitektur dimulai dengan dibangunnya Ka'bah oleh Nabi Adam 'Alaihi Salam sebagai pusat beribadah umat manusia kepada Allah SWT (Saoud, 2002).

Konsep Arsitektur Islam berkembang karena kecenderungan masuknya budaya daerah (vernacularism). Bentuk setempat kadang menjadi ciri regionalism arsitektur. Karya arsitektur yang paling banyak dibahas dan dianggap memiliki konsepkonsep Arsitektur Islam adalah masjid. Sebagaimana yang kita ketahui, bahwa Arsitektur Islam mengusung nilai-nilai ajaran Islam yang tertuang pada Al Qur'an. Nilai-nilai ini diterjemahkan kedalam bahasa arsitektur dan terwujud dalam bentuk tergantung konteks dan fungsinya dengan tidak melupakan esensi dari arsitektur itu sendiri, dan tetap berpegang pada tujuan utama berasitektur yaitu untuk beribadah kepada Allah SWT. Arsitektur termasuk di dalam seni ruang dalam esensi seni menurut Islam, hal ini dikarenakan arsitektur merupakan seni visual yang mendukung kemajauan peradaban Islam.

Pengembangan seni ruang termasuk di dalam arsitektur, yang berdasarkan pada nilai-nilai Al Qur'an memiliki ciri-ciri utama yang dimiliki semua seni Islam, sebagai berikut (Al Faruqi, 1999):

1. Unit-unit isi

2. Arsitektur atau struktur dengan ruang interior

3. Lanskaping (holtikultura maupun akuakultura)

4. Desain kota dan desa

Tabel 1 berikut merupakan 12 parameter yang digunakan untuk menilai suatu seni dekorasi Islam, apakah sesuai dengan maksud dari simbol arsitektur Islam ataukah tidak. Parameter ini yang digunakan untuk menilai seni Islam pada Masjid Hj. Sudalmiyah Rais.

Table 1. Parameter Unsur-unsur Simbolis Arsitektur Islam

\begin{tabular}{|l|l|l|}
\hline No & Simbolis & Parameter \\
\hline 1 & Keseimbangan Simetris & $\begin{array}{l}\text { Mempunyai objek yang sama antara kanan-kiri dari titik } \\
\text { seimbang }\end{array}$ \\
\hline 2 & Bentuk Geometris & $\begin{array}{l}\text { Mempunyai lay out yang tegas antara persegi dan } \\
\text { lingkaran }\end{array}$ \\
\hline 3 & Fasade Dekoratif & Mempunyai permukaan yang bertekstur atau pola tertentu \\
\hline 4 & Komposisi Repetitif & Pengulangan bentuk yang sama pada bagian yang berbeda \\
\hline 5 & Omamen Florist & Hiasan yang bercorak/berpola dedaunan \\
\hline 6 & Omamen Geometris & Hiasan yang berbentuk kotak/lingkaran \\
\hline 7 & Omamen Kaligrafis & Hiasan yang berbentuk tulisan arab \\
\hline 8 & Hand Made & Hasil kerajinan/keterampilan/keahlian tangan. \\
\hline 9 & Warna Alami & Sesuai warna material \\
\hline 10 & Lobang Berpola & Permukaan berlobang kotakan/lengkungngan \\
\hline 11 & Plesteran Berpola & Permukaan ditutupi plesteran \\
\hline 12 & Bata/Batu Berpola & Permukaan ditutupi bata/batu berpola \\
\hline
\end{tabular}

(sumber: Ernest Burden, 1995 dalam Qomarun, 2004)

Seni Islam atau dapat disebut seni rupa Islam merupakan elemen fisik yang memiliki unsur-unsur simbolis nilai Islam baik dalam corak atau bentuk arsitekturalnya. Seni hias Islam yaitu ornamen. Kata ornamen berasal dari bahasa Latin ornare, yang berarti menghiasi. Menurut Gustami (2008) ornamen adalah komponen produk seni yang ditambahkan atau sengaja dibuat untuk tujuan hiasan. Pola ornamen dalam seni rupa Islam yang biasa digunakan dan sering diterapkan terdiri dari pola-pola hiasan ilmu ukur dan pola-pola hiasan polygonal yang dilebur menjadi satu dalam bentuk hiasan dekoratif. Menurut Achmad Fanani (2009) terdapat empat corak ornamen yang sering digunakan dalam dekorasi Islam, yaitu: [1] ornamen corak floral, [2] ornamen corak geometrik, [3] ornamen muqarrnas atau dekorasi sarang tawon, dan [4] ornamen kaligrafi.

\section{METODE PENELITIAN}

Dalam penelitian ini menggunakan metode penelitian kualitatif. Dalam penelitian kualitatif data yang dikumpulkan berupa deskriptif (Prastowo, 2012). Penelitian kualitatif merupakan penelitian yang menggunakan metode pengumpulan data bersifat terbuka dan data yang terkumpul cenderung berupa data teks, objek atau gambar, bukan berupa angka, disebabkan tujuan penelitian ini adalah untuk menunjukan dan memaparkan atau mendiskripsikan seni Islam pada Masjid Hj. Sudalmiyah Rais UMS. Data yang diperoleh berupa gambar yang sesuai dengan ornamen Islam yang digunakan pada Masjid $\mathrm{Hj}$. Sudalmiyah Rais UMS.

Pengumpulan data dilakukan pada natural setting (kondisi alamiah). Teknik pengumpulan data terkait dengan maksud dan tujuan penelitian terdapat beberapa teknik yang dilakukan yaitu dengan:

\section{Observasi}


Pengumpulan data lebih banyak pada observas berperan serta (participant observation) atau pengamatan secara langsung. Data yang didapat berupa data gambar yang bersifat aktual dan faktual.

2. Studi Literatur

Studi literatur diperoleh dari mengkaji pustaka beberapa buku, jurnal penelitian yang sudah dilakukan atau teori seni Islam yang digunakan sebagai parameter/tolok ukur data dan digunakan untuk menganalisa data yang diperoleh.

Beberapa alat utama yang digunakan dalam penelitian ini adalah alat tulis dan kamera. Alat tulis digunakan untuk mencatat data observasi langsung pada objek penelitian. Alat tulis berupa pensil, kertas, pena. Alat kamera digunakan untuk pengambilan gambar objek atau pengambilan data visual.

Observasi mendalam dilakukan pada penelitian ini, untuk mendapatkan data yang aktual dan faktual. Data berupa gambar didokumentasikan dan dianalisa seusai dengan parameter yang didapat dari studi literatur/studi pustaka dalam unsur-unsur simbolis arsitektur Islami (Ernest Burden dalam Qomarun, 2004) dan empat macam kategori seni hias Islam (Fanani, 2009). Penyajian data dibuat dalam susunan data gambar atau data yang didapat dari lapangan kemudian diidentifikasi dan dianalisa sesuai dengan parameter studi literatur/studi pustaka.

\section{HASIL DAN PEMBAHASAN}

Penelitian seni Islam pada Masjid $\mathrm{Hj}$. Sudalmiyah Rais UMS dilakukan untuk mendapat data tentang elemen fisik wujud arsitektur Islam yang terdapat pada bangunan berdasarkan observasi studi pustaka parameter dari unsur-unsur simbolis arsitektur Islami. Data sebagai hasil hasil observasi dapat dilihat pada Tabel 2.

Table 2. Data Penelitian

\begin{tabular}{|c|c|c|c|c|}
\hline No & Simbolis & Parameter & Fakta & Ket \\
\hline 1 & $\begin{array}{l}\text { Keseim } \\
\text { bangan } \\
\text { Simetris }\end{array}$ & $\begin{array}{l}\text { Mempunyai } \\
\text { denah yang } \\
\text { sama antara } \\
\text { kanan-kiri } \\
\text { dari titik } \\
\text { seimbang. }\end{array}$ & denah & V \\
\hline 2 & $\begin{array}{l}\text { Bentuk } \\
\text { Geome } \\
\text { tris }\end{array}$ & $\begin{array}{l}\text { Mempunyai } \\
\text { lay out yang } \\
\text { tegas antara } \\
\text { persegi dan } \\
\text { lingkaran. }\end{array}$ & denah & V \\
\hline 3 & $\begin{array}{l}\text { Fasade } \\
\text { Dekora } \\
\text { tif }\end{array}$ & $\begin{array}{l}\text { Mempunyai } \\
\text { permukaan } \\
\text { yang } \\
\text { bertekstur } \\
\text { atau pola } \\
\text { tertentu }\end{array}$ & ntu uta & V \\
\hline
\end{tabular}

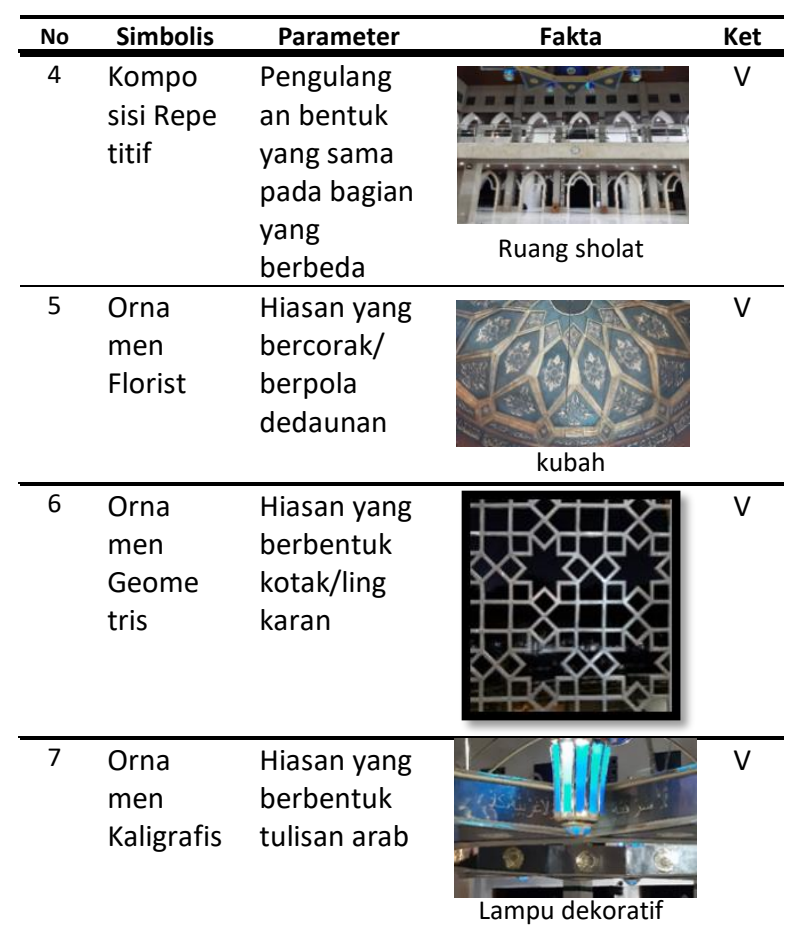

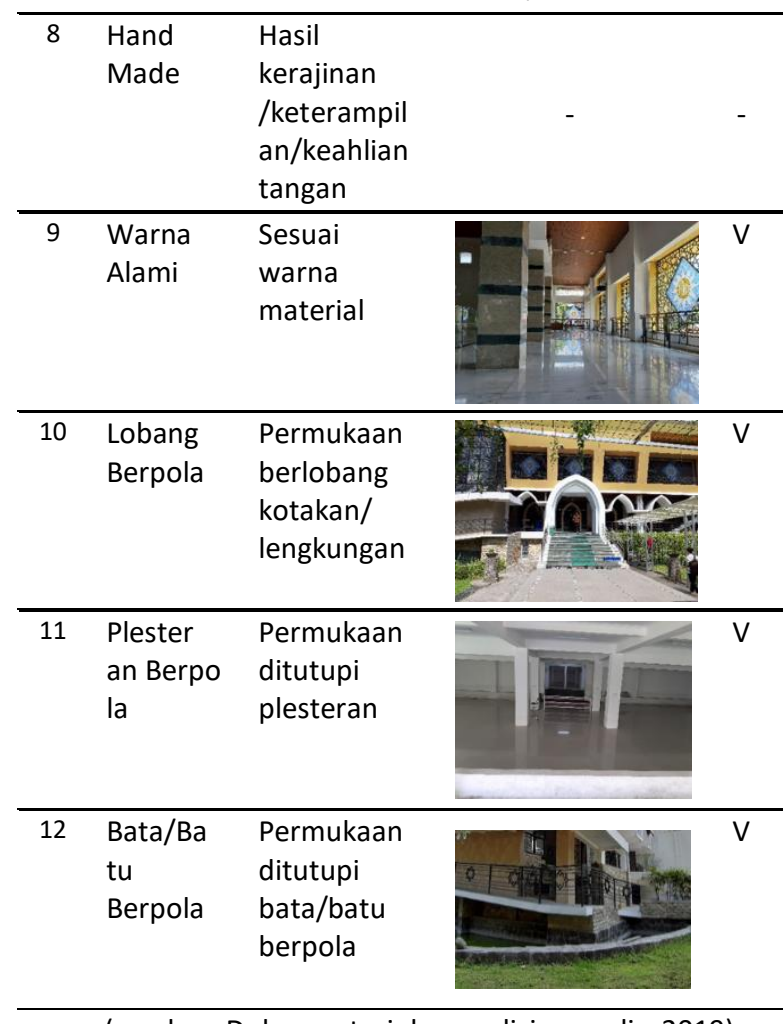

(sumber: Dokumentasi dan analisis penulis, 2019)

Keseimbangan simetris pada masjid $\mathrm{Hj}$. Sudalmiyah Rais terdapat pada bentuk landscape taman, denah bangunan serta fasad/tampak masjid. Hampir seluruh bentuk fisik masjid dibangun sesuai gambar desain tim perancangan, terkecuali pada kubah masjid yang diganti menggunakan kubah berornamenkan kaligrafi dan florist. Namun saat peresmian kubah masjid sudah sesuai gambar desain perancangan yaitu menggunakan kubah enamel 
rangka besi pipa desain fabrikasi. Bentuk geometris tercermin pada denah dan landskape masjid. Fasad masjid dekoratif dengan gabungan antara lobang berpola dan cerukan pintu masuk masjid, pada bagian tengah fasad depan atau timur masjid. Komposisi repetitif masjid terdapat pada cerukan atau lobang berpola pada pintu masuk atau jalan masuk dan pada cerukan dinding antar kolom masjid. Ornamen florist dan kaligrafi terdapat pada kubah, ornamen kaligrafi juga terdapat pada lampu gantung serta penutup bangunan masjid. Ornamen geometris terdapat pada hiasan penutup atau pelingkup selubung bangunan masjid. Bangunan masjid mempertahankan warna asli dari material yang digunakan yaitu marmer sebagai penutup lantai, dinding interior Masjid $\mathrm{Hj}$. Sudalmiyah Rais serta kolom. Kemudian batu alam yang terdapat pada eksterior masjid juga dipertahankan warnanya. Seluruh dinding pada semi basement ditutup plester dan dicat putih. Pada eksterior dan detail landscape masjid terdapat penggunaan batu alam. Unsur-unsur simbolis arsitektur Islam inilah yang memperlihatkan elemen-elemen arsitektural pada bangunan masjid. Seni Islam pada bangunan masjid memiliki satu corak yang khas yaitu seni hias Islam bentuk geometris.

\section{Seni Hias Islami pada Masjid Hj. Sudalmiyah Rais UMS}

\section{Eksterior}

Teridentifikasi ornamen geometris ciri khas Islam berbentuk bintang segi delapan (octagonal star shapes) pada hiasan penutup (overlay) pada sekeliling masjid kecuali pada muka belakang masjid. Bagian tengah penutup (overlay) terdapat ornamen kaligrafi yang bertuliskan "Allah" dan "Muhammad".
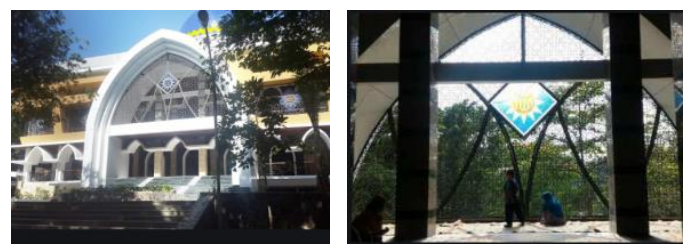

Gambar 1. Muka Depan Masjid (sumber: Dokumentasi Penulis, 2019)

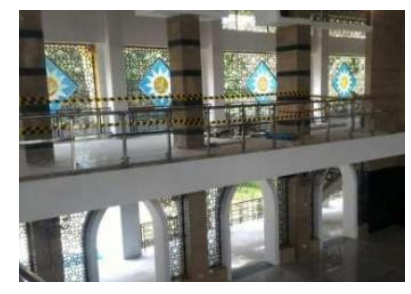

Gambar 2. Tampak samping dari dalam ruang masjid (sumber: Dokumentasi Penulis, 2019)

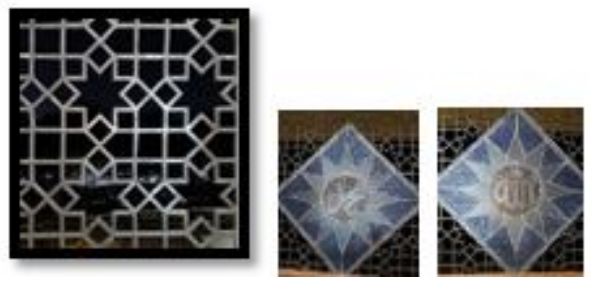

Gambar 3. Ornamen Geometris dan kaligrafi (sumber: Dokumentasi Penulis, 2019)

2. Interior

\section{a. Mihrab}

Mihrab Masjid Hj. Sudalmiyah Rais UMS dihiasi dengan ornamen geometris segi delapan (octagonal shapes) yang terdapat pada bagian depan menempel pada dinding luar berbentuk ceruk kedalam. Dibagian dalam bagian tengah mihrab terdapat ornamen kaligrafi.

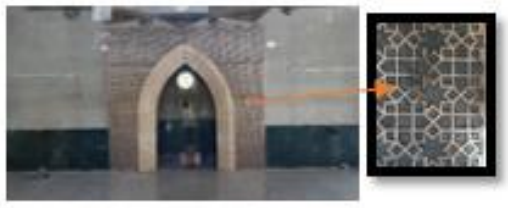

Gambar 4. Ornamen Geometris pada Mihrab (sumber: Dokumentasi Penulis, 2019)

Permainan pola ornamen bintang segi delapan ini secara simbolis menjadi perlambang kesamaan radiasi dalam semua arah melalui satu titik. Dapat diartikan juga bahwa Islam menyebar ke segala penjuru melaui satu titik. Keberadaan mihrab ini berornamentasi menonjol yang bertujuan memperkuat kedudukan mihrab sebagai penunjuk arah kiblat juga sebagai point of interest interior masjid.

b. Kubah

Pada bagian Kubah terdapat dua ornamen, yaitu ornamen florist dan ornamen kaligrafi. Ornamen florist terdapat pada bagian langit-langit kubah sedangkan ornamen kaligrafi terdapat melingkar pada bagian bawah kubah. Ornamen floral digabungkan dengan bentuk segi delapan yang berada ditengahnya dan dikelilingi oleh sulur-sulur.
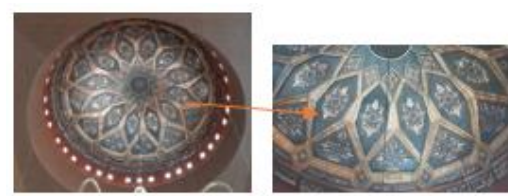

Gambar 5. Ornamen florist pada kubah (sumber: Dokumentasi Penulis, 2019)

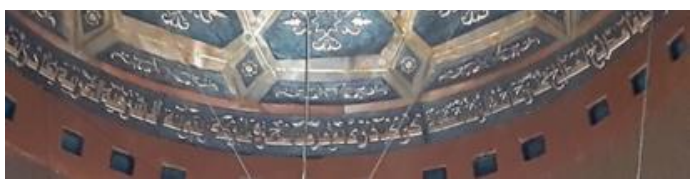

Gambar 6. Ornamen kaligrafi pada kubah (sumber: Dokumentasi Penulis, 2019) 
Ornamen kaligrafi pada kubah juga nampak di bagian luar kubah dan di atasnya terdapat ornamen kaligrafi bertuliskan "Allah" yang juga berfungsi sebagai penangkal petir dan penanda bahwa bangunan tersebut adalah masjid.

c. Lampu Gantung

Pada lampu gantung teridentifikasi adanya ornamen kaligrafi bertuliskan:

"Allahu nurus samawati wal-ard(i), masalu nurihi kamisykatin fiha misbah(un), al misbahu fi zujajah(tin) az-zujajatun ka'annaha kaukabun durriyuy yuqadu min syajaratim mubarakatin zaitunatil la syarqiyyatiw wa la garbiyyatiy yakadu zaituha yudi'u wa lau lam tamsashu nar(un), nurun 'ala nur(in), yahdillahu linurihi may yasya'(u), wa yadribullahul-amsala linnas(i), wallahu bi kulli sai'in 'alim(un) "

Q.S An-Nur, ayat 35.

Artinya: Allah (pemberi) cahaya (kepada) langit dan bumi. Perumpaman cahaya-Nya, seperti sebuah lubang yang tidak tembus yang di dalamnya ada pelita besar. Pelita itu di dalam tabung kaca, (dan) tabung kaca itu bagaikan bintang yang berkilauan, yang dinyalakan dengan minyak dari pohon yang diberkahi, (yaitu) pohon zaitun yang tumbuh tidak di timur tidak pula di barat, yang minyaknya (saja) hampir-hanpir menerangi, walaupun tidak disentuh api. Cahaya di atas cahaya (berlapislapis), Allah memberi petunjuk cahaya-Nya bagi orang yang Dia kehendaki, dan Allah membuat perumpamaan-perumpamaan bgi manusia. Dan Allah Maha Mengetahui segala sesuatu.

Q.S An-Nur, ayat 35 .

Seni hias Islam yang terdapat di lampu gantung tersebut adalah simbolisasi dari kaligrafi Qs An-Nur ayat 35 , yang tafsirnya sesuai dengan makna filosofis dari sebuah lampu.
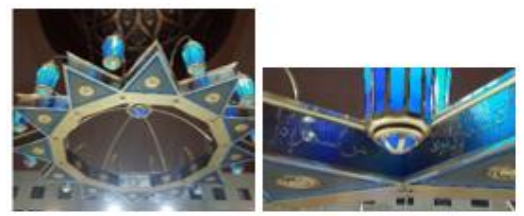

Gambar 7. Ornamen kaligrafi pada lampu gantung (sumber: Dokumentasi Penulis, 2019)

\section{KESIMPULAN}

Berdasarkan hasil pencocokan parameter unsurunsur simbolis arsitektur islami, Masjid $\mathrm{Hj}$. Sudalmiyah Rais memenuhi 11 dari 12 parameter tersebut. Adapun ornamentasi berasal dari kerajian tangan atau handmade tidak terdapat di masjid ini, sehingga dapat disimpulkan Masjid $\mathrm{Hj}$. Sudalmiyah Rais menerapkan seni Islam pada wujud fisik bangunan. Seni Hias Islami yang terdapat pada Masjid $\mathrm{Hj}$. Sudalmiyah Rais yaitu berupa ornamen kaligrafi, ornamen geometris dan ornamen florist. Setiap ornamen yang ada pada Masjid Hj. Sudalmiyah Rais memiliki nilai keagamaan yaitu nilai akidah mengenai keyakinan terhadap Allah, yang Maha Pemberi Cahaya dan Maha Pemberi Petunjuk kepada umatNya. Kaligrafi sebagai simbolisasi bernilai syariah yang digunakan pada arsitektur masjid sesuai dengan Hadits Rasulullah SAW.

Macam jenis ornamen yang terdapat pada masjid Hj. Sudalmiyah Rais berjumlah 3 dari ke-4 kategori, sesuai pendapat Ahcmad Fanani (2009). Ornamen yang terdapat di masjid berupa 1] ornamen muqarrnas atau sarang lebah, 2] ornamen geometris segi delapan (octagonal star shapes) pada masjid terdapat pada seluruh penutup (overlay) masjid kecuali dinding muka belakang masjid yang dikombinasikan dengan ornamen kaligrafi bertuliskan "Allah" dan "Muhammad" pada tengahnya di dalam kaca segi 12, dan 3] ornamen kaligrafi, yang ditemukan pada kubah, berbentuk melingkar mengikuti bentuk kubah. Sedangkan ornamen florist terdapat pada langit-langit kubah berpadukan dengan pola-pola segi enam yang membentuk geometri dasar kubah. Selain itu ornamen kaligrafi juga ditemukan pada lampu gantung segi 12 yang setiap sisinya terdapat kaligrafi yang bertuliskan ayat Al Qur'an surat An-Nur ayat 35.

Setiap ornamen pada arsitektur Islam tidak hanya berfungsi sebagai hiasan atau pengisi saja melainkan memiliki makna, simbol dan nilai Islami yang ingin disampaikan, inilah yang menjadi ciri seni hias Islami. Karena arsitektur tidak lain bertujuan untuk beribadah dan memuji kebesaran Allah SWT. Tujuan ini menjadikan prinsip-prinsip perancangan arsitektur Islam selalu berada pada koridor nilai-nilai dan pandangan hidup islami.

\section{DAFTAR PUSTAKA}

Al Faruqi, Ismail Raji, 1999. Seni Tauhid Esensi dan Estetika Islam. Yogyakarta: Yayasan Bentang Budaya.

Fanani, Achmad, 2009. Arsitektur Masjid. Bentang Pustaka: Yogyakarta.

Gustami, SP, 2008. Nukilan Seni Ornamen Indonesia. Institut Seni Indonesia: Yogyakarta.

Latif, F. (2015). Perbedaan Karakteristik Desain Interior dan Bangunan Masjid Moderen dengan Masjid Tradisional (Studi Kasus Masjidmasjid di Jakarta). Bandung: UPT Perpustakaan ITB.

Nurjayanti, W, 2011. Kauman Surakarta Housing Pattern. Prosiding Seminar Internasional Integrating Islam and Knowledge: Social Sciences and Technology. UMS: Surakarta.

Nurjayanti, W, Arya Ronald, 2011. Rekayasa Model Disain Rumah Islami berdasarkan Studi Eksplorasi di Permukiman Sekitar Masjid 
Menara Kudus. Prosiding Simposium Nasional RAPI X, ISSN:1412.9612, Edisi 13 Desember 2011. Prodi Arsitektur FT UMS: Surakarta.

Prastowo, Andi, 2012. Metode Penelitian Kualitatif: dalam Perspektif Rancangan Peneitian. ArRuszz Media: Yogyakarta.

Qomarun, 2004. Eksplorasi tentang Islam, Arsitektur dan Arsitektur Islam: Studi kasus pada Lingkungan Binaan di Kampus UMS. Prosiding Simposium Nasional Arsitektur Islam. Arsitektur UMS: Surakarta.

Saoud, Rabah, 2002. An Introduction to Islamic Architecture. FSTC Limited: Manchester. 